\title{
Uric acid as a monitor of oxidative stress in a random skin flap in rats ${ }^{1}$
}

\author{
Sueli Teresinha Freire ${ }^{2}$ \\ Lydia Masako Ferreira ${ }^{3}$ \\ Heitor Carvalho Gomes ${ }^{4}$ \\ Sandro Percario ${ }^{5}$
}

\begin{abstract}
Freire ST, Ferreira LM, Gomes HC, Percario S. Uric acid as a monitor of oxidative stress in a random skin flap in rats. Acta Cir Bras [serial online] 2003 Nov-Dec;18(6). Available from URL: http://www.scielo.br/acb.

ABSTRACT - Purpose: To verify the possible role of uric acid as a monitor of oxidative stress in a random skin flap, in the rat. Methods: This study utilized 21 adult male Wistar-EPM rats divided, at random, in three groups of seven animals, to evaluate the behavior of uric acid levels during oxidative stress zero, 5 and 15 minutes after elevation of the flap. According toS the time schedule, skin samples were collected in order to allow determination of uric acid and malondialdehyde (MDA) levels. Results: Uric acid levels in the skin samples did not change with time, but the values in normal skin were higher since the beginning. Malondialdehyde (MDA) levels in the skin samples remained stable throughout. Conclusion: Uric acid levels in the flap skin were lower than those in the normal skin, denoting local oxidative stress.
\end{abstract}

KEY WORDS - Surgical flaps. Lipid peroxidation. Uric acid. Rats.

\section{Introduction}

Skin flaps necrosis is a matter of great concern to the Plastic Surgeons. In order to reduce the risk of it, many experimental studies have been carried out, specially in the field of oxidative stress and antioxidants. Oxidative stress is a phenomenon that occurs after elevation of ischemic flaps, with excessive production of free radicals and damage to the cells. Antioxidants are substances that reduce or block the deleterious effects of these radicals ${ }^{1,2}$. Uric acid is an endogen antioxidant and represents part of the tissues' natural defense against oxidative stress. It is an important antioxidant in the serum, representing a final product in the metabolism of the purines and acts as a potent free radical scavenger, inhibiting lipid peroxidation ${ }^{3}$. Malondialdehyde (MDA) is a product of lipid peroxidation, helpful in studies that deal with oxidative stress, serving as a quantifier of the aggression suffered by the tissues ${ }^{4}$.This study determined the levels of both uric acid and MDA in skin samples, at early stages after elevation of a random skin flap and it aims to elucidate the role of this acid in this model of oxidative stress.

\section{Methods}

Twenty-one adult male Wistar-EPM rats were divided into three groups of seven animals: an immediate postoperative (GPOI), a five-minute postoperative (GPO5) and a fifteen-minute postoperative group (GPO15). After anesthesia with pentobarbital $(40 \mathrm{mg} / \mathrm{kg})$ intraperitoneally, the rats were shaved and a random skin flap was elevated, with a cranial base, measuring 10x4 cm, on the back of the animals ${ }^{5}$. After that, and according to the time schedule, skin samples were collected in order to allow determination of uric acid and MDA levels. One sample was obtained from the middle of the flap $(5 \mathrm{~cm}$ from the base), another from the distal end, and one more, distant from the flap, from a normal skin area.

\section{Results}

Uric acid levels in the skin samples in the middle of the flap ranged between $1.9 \mathrm{mg} / \mathrm{dl}$ and $8.6 \mathrm{mg} / \mathrm{dl}$ (average $4.9 \mathrm{mg}$ / dl), $1 \mathrm{mg} / \mathrm{dl}$ and $13 \mathrm{mg} / \mathrm{dl}$ (average $4.6 \mathrm{mg} /$ dl) and $0.9 \mathrm{mg} / \mathrm{dl}$ and $11.2 \mathrm{mg} / \mathrm{dl}$ (average $4.9 \mathrm{mg} / \mathrm{dl}$ ), in groups POI, PO5 and PO15, respectively.

Distal end of the flap's uric acid values ranged between $1.5 \mathrm{mg} / \mathrm{dl}$ and 6.1 $\mathrm{mg} / \mathrm{dl}$ (average $3.6 \mathrm{mg} / \mathrm{dl}$ ), $1.2 \mathrm{mg} / \mathrm{dl}$ and $13.3 \mathrm{mg} / \mathrm{dl}$ (average $5.6 \mathrm{mg} / \mathrm{dl}$ ) and $1.1 \mathrm{mg} /$ $\mathrm{dl}$ and $11.2 \mathrm{mg} / \mathrm{dl}$ (average $5.6 \mathrm{mg} / \mathrm{dl}$ ), in groups POI, PO5 and PO15, respectively.

Uric acid values in normal skin samples ranged between $3.6 \mathrm{mg} / \mathrm{dl}$ and 8.1 $\mathrm{mg} / \mathrm{dl}$ (average $5.2 \mathrm{mg} / \mathrm{dl}$ ), $2.5 \mathrm{mg} / \mathrm{dl}$ and $28.6 \mathrm{mg} / \mathrm{dl}$ (average 10,7 mg/dl) and 2.5 $\mathrm{mg} / \mathrm{dl}$ and $13 \mathrm{mg} / \mathrm{dl}$ (average $6.6 \mathrm{mg} / \mathrm{dl}$ ), in groups POI, PO5 and PO15, respectively.

Malondialdehyde (MDA) levels in the skin samples in the middle of the flap ranged between $1282 \mathrm{ng} / \mathrm{ml}$ and $21558 \mathrm{ng} / \mathrm{ml}$

1. Trabalho da Disciplina de Cirurgia Plástica da Universidade Federal de São Paulo - Escola Paulista de Medicina (UNIFESP - EPM).

2. Mestre em Medicina pelo Programa de Pós-Graduação em Cirurgia Plástica Reparadora da UNIFESP - EPM.

3. Professora Titular da Disciplina de Cirurgia Plástica da UNIFESP - EPM.

4. Professor Colaborador Doutor da Disciplina de Cirurgia Plástica da UNIFESP - EPM.

5. Professor Colaborador Doutor da Disciplina de Cirurgia Vascular da UNIFESP - EPM. 
(average $8310 \mathrm{ng} / \mathrm{ml}), 2565 \mathrm{ng} / \mathrm{ml}$ and 13021 $\mathrm{ng} / \mathrm{ml}$ (average $7062 \mathrm{ng} / \mathrm{ml}$ ) and $1427 \mathrm{ng} / \mathrm{ml}$ and $13021 \mathrm{ng} / \mathrm{ml}$ (average $6083 \mathrm{ng} / \mathrm{ml}$ ), in groups POI, PO5 and PO15, respectively.

Distal end of the flap's MDA levels ranged between $1220 \mathrm{ng} / \mathrm{ml}$ and $10425 \mathrm{ng} /$ $\mathrm{ml}$ (average $5648 \mathrm{ng} / \mathrm{ml}$ ), $2275 \mathrm{ng} / \mathrm{ml}$ and 9756 $\mathrm{ng} / \mathrm{ml}$ (average $5831 \mathrm{ng} / \mathrm{ml}$ ) and $1531 \mathrm{ng} / \mathrm{ml}$ and $11959 \mathrm{ng} / \mathrm{ml}$ (average $5731 \mathrm{ng} / \mathrm{ml}$ ), in groups POI, PO5 and PO15, respectively.

MDA values in normal skin samples ranged between $3930 \mathrm{ng} / \mathrm{ml}$ and $14398 \mathrm{ng} /$ $\mathrm{ml}$ (average $10464 \mathrm{ng} / \mathrm{ml}$ ), $2795 \mathrm{ng} / \mathrm{ml}$ and $14398 \mathrm{ng} / \mathrm{ml}$ (average $6847 \mathrm{ng} / \mathrm{ml}$ ) and 1800 $\mathrm{ng} / \mathrm{ml}$ and $6530 \mathrm{ng} / \mathrm{ml}$ (average $4042 \mathrm{ng} / \mathrm{ml}$ ), in groups POI, PO5 and PO15, respectively.

Variance Analyzis showed higher levels of uric acid in the normal skin samples than in the middle and distal end of the flap samples. No statistical differences were found as regards MDA levels in the skin samples (Tables 1-6).

\section{Discussion}

Ischemia and necrosis are important complications in Plastic Surgery. Random pattern skin flaps are particularly sensitive and measures to reduce this risk have been studied. The action of oxidative stress upon random surgical flaps has been pointed out but not completelly elucidated yet.

The early events that take place after elevation of random skin flaps are particularly interesting, for an adequate understanding of this period may allow the surgeon to take control of this physiopathological situation and avoid the failure of the operative procedure.

The rat skin is similar to the human skin, with diferences as regards the tissue underneath the dermis. In the rat, the muscular layer (=panniculus carnosus) is more adhered to the skin while in the human, the subcutaneous tissue is more adhered to the deep fascia. Nevertheless, the blood supply to the skin is similarly associated with these layers, which contains the main nutrient vessels.

McFarlane's flap represents an efficient tool to work with when random skin flaps are studied in the rat. It is well suited to ischemia/reperfusion studies because after flap elevation a hyperadrenergic state takes place, due to noradrenalin accumulation after section of sympatic nerves, and the resultant vasoconstriction leads to a temporary, but complete, capillary oclusion. Reperfusion of the distal ischemic skin occurs after noradrenalin removal, with resultant capillary dilation 6 .

As this particular study focused on the early events after elevation of the flap, there was no distal necrotic area to be quantified. Skin samples were collected from the middle of the flap and distal flap areas as well as from normal skin.
Uric acid is an endogen antioxidant and takes part in the tissues natural defense against oxidative stress. An important serum antioxidant, it represents a final product in the metabolism of the purines, acting as a potent free radical scavenger and inhibitor of lipid peroxidation ${ }^{3}$. Beying an antioxidant that

TABLE 1 - Concentration of Uric Acid (mg/dl) from the middle of the flap skin samples at zero, 5 and 15 minutes $\mathrm{PO}$

\begin{tabular}{cccc}
\hline Animal & POI $(0 \mathrm{~min})$ & PO5 $(5 \mathrm{~min})$ & PO15 $(15 \mathrm{~min})$ \\
\hline 1 & 1.9 & 3.4 & 2.2 \\
2 & 3.6 & 13 & 9.1 \\
3 & 3.2 & 4.5 & 7 \\
4 & 8.1 & 6.6 & 11.2 \\
5 & 8.6 & 1.5 & 2.5 \\
6 & 4.1 & 2.4 & 1.8 \\
7 & 4.9 & 1 & 0.9 \\
Average & 4.9 & 4.6 & 5 \\
\hline
\end{tabular}

TABLE 2 - Concentration of Uric Acid (mg/dl) from the distal end of the flap skin samples at zero, 5 and 15 minutes PO.

\begin{tabular}{cccc}
\hline Animal & POI $(0 \mathrm{~min})$ & PO5 $(5 \mathrm{~min})$ & PO15 $(15 \mathrm{~min})$ \\
\hline 1 & 6.1 & 5.8 & 6.6 \\
2 & 2.5 & 5.6 & 9.1 \\
3 & 1.5 & 7.7 & 7 \\
4 & 4.5 & 13.3 & 11.2 \\
5 & 3.6 & 1.7 & 1.8 \\
6 & 3.4 & 4.1 & 1.1 \\
7 & 3.5 & 1.2 & 2.7 \\
Average & 3.6 & 5.6 & 5.6 \\
\hline
\end{tabular}

TABLE 3 - Concentration of Uric Acid (mg/dl) from the normal skin samples at zero, 5 and 15 minutes $\mathrm{PO}$.

\begin{tabular}{cccc}
\hline Animal & POI $(0 \mathrm{~min})$ & PO5 $(5 \mathrm{~min})$ & PO15 $(15 \mathrm{~min})$ \\
\hline 1 & 3.9 & 4.2 & 6.1 \\
2 & 4 & 28.6 & 13 \\
3 & 6.2 & 21.2 & 8.8 \\
4 & 3.6 & 9.7 & 10 \\
5 & 6.1 & 2.5 & 2.9 \\
6 & 8.1 & 5.3 & 2.8 \\
7 & 4.8 & 3.4 & 2.5 \\
Average & 5.2 & 10.7 & 6.6 \\
\hline
\end{tabular}

TABLE 4 - Concentration of MDA (ng/ml) from the middle of the flap skin samples at zero, 5 and 15 minutes PO.

\begin{tabular}{cccc}
\hline Animal & POI $(0 \mathrm{~min})$ & PO5 $(5 \mathrm{~min})$ & PO15 $(15 \mathrm{~min})$ \\
\hline 1 & 1282 & 2565 & 1427 \\
2 & 9481 & 13030 & 13021 \\
3 & 1534 & 8179 & 8183 \\
4 & 21558 & 7613 & 7711 \\
5 & 3816 & 7974 & 4580 \\
6 & 9914 & 6806 & 5290 \\
7 & 10582 & 3174 & 2369 \\
Average & 8310 & 7062 & 6083 \\
\hline
\end{tabular}


TABLE 5 - Concentration of MDA $(\mathrm{ng} / \mathrm{ml})$ in the distal end of the flap skin samples at zero, 5 and 15 minutes PO.

\begin{tabular}{cccc}
\hline Animal & POI $(0 \mathrm{~min})$ & PO5 $(5 \mathrm{~min})$ & PO15 $(15 \mathrm{~min})$ \\
\hline 1 & 1220 & 2275 & 1531 \\
2 & 1730 & 9756 & 1888 \\
3 & 2675 & 8694 & 10308 \\
4 & 8536 & 3541 & 11959 \\
5 & 5350 & 6394 & 4437 \\
6 & 9599 & 7312 & 6206 \\
7 & 10425 & 2842 & 3791 \\
Average & 5648 & 5831 & 5731 \\
\hline
\end{tabular}

TABLE 6 - Concentration of MDA (ng/ml) in the normal skin samples at zero, 5 and 15 minutes PO.

\begin{tabular}{cccc}
\hline Animal & POI $(0$ min $)$ & PO5 $(5$ min $)$ & PO15 $(15$ min $)$ \\
\hline 1 & 3930 & 3640 & 2172 \\
2 & 14398 & 14270 & 3698 \\
3 & 10976 & 8222 & 6530 \\
4 & 12707 & 7789 & 4603 \\
5 & 6570 & 2795 & 5464 \\
6 & 13375 & 6570 & 4027 \\
7 & 11291 & 4516 & 1800 \\
Average & 10464 & 6847 & 4042 \\
\hline
\end{tabular}

is present in the tissues, accompaning probable variations in its levels since the very early phases after flap elevation may allow us to use it as a monitor of oxidative stress. As no articles were found in the Literature envolving uric acid levels in the early phases after elevation of a random pattern skin flap, the authors decided to study the subject in the rat.

The finding of higher levels of uric acid from the normal skin samples, when compared to those from the middle and from the distal end of the flap (Variance Analyzis), since POI and extending into PO15, suggests that the oxidative reactions envolving consumption of uric acid were so early and fast, that even the POI period failed to identify their beggining. Indeed, the maintenance of uric acid levels in the skin samples obtained from the flap throughout all the study suggests that the uric acid in the flap was consumed early and fast (before POI), and that this consumption also stopped early.

Malondialdehyde (MDA), a product of lipid peroxidation, is often used in studies that deal with oxidative stress, acting as a quantifier of the aggression suffered by the tissues. Its levels were determined via a modified Kohn, Liversedge method ${ }^{4}$. MDA levels in the skin samples were high, corroborating the hypothesis of the local occurrence of oxidative stress. Comparison among the different skin samples from different periods revealed no difference (Variance Analyzis), indicating that, at least, the oxidative stress remained stable throughout.

This study unveiled a small part of the complex oxidative phenomenon that occurs after elevation of a random pattern skin flap in the rat, and even trying to identify the very early events as regards uric acid and malondialdehyde levels, the study faced extremely fast pathophysiological reactions.

\section{Conclusion}

Uric acid levels in the flap skin were lower than those in the normal skin, denoting local oxidative stress.

\section{References}

1. Gomes HC, Bueno PCS, Scardoeli CAC, Percario S, Landman MRL, Ferreira LM. Effect of $\mathrm{N}$ - acetylcysteine in a random skin flap after administration of nicotine, in the rat. F Med 1998; 117: 209-11.

2. Duarte IS, Gomes HC, Ferreira LM. Effect of dimethyl sulphoxide on necrosis of skin flaps in rats. Can J Plast Surg 1998; 6: 93-7.

3. Halliwell B, Gutteridge JMC. Free radicals in biology and medicine. Oxford: Clarendon Press; 1985.

4. Percario S, Vital ACC, Jablonka F. Dosagem do malonaldeído. Newslab 1994; 6: 46-50.

5. McFarlane RM, DeYoung G, Henry RA. The design of a pedicle in the rat to study necrosis and its prevention. Plast Reconstr Surg 1965; 35: 245-8.

6. Pearl RM. A unifying theory of the delay phenomenon: recovery from the hyperadrenergic state. Ann Plast Surg 1981; 7: $102-12$.

Freire ST, Gomes HC, Ferreira LM, Percario S. Ácido úrico como monitor do estresse oxidativo em um retalho cutâneo randômico em ratos. Acta Cir Bras [serial online] 2003 Nov-Dez;18(6). Disponível em URL: http://www.scielo.br/acb.

RESUMO - Objetivo: Verificar o possível papel do ácido úrico como monitor do estresse oxidativo em um retalho cutâneo randômico, no rato. Métodos: Este estudo utilizou 21 ratos adultos Wistar-EPM, divididos, ao acaso, em três grupos de sete animais, para avaliar o comportamento dos níveis de ácido úrico durante o estresse oxidativo, aos zero, 5 e 15 minutos após a elevação do retalho. De acordo com os períodos de tempo estabelecidos, amostras de pele foram coletadas de modo a permitir a determinação dos níveis de ácido úrico e malondialdeído (MDA). Resultados: Os níveis de ácido úrico nas amostras de pele não variaram com o tempo, mas os valores na pele normal foram maiores desde o início. Os níveis de malondialdeído (MDA) nas amostras de pele permaneceram estáveis. Conclusão: Os níveis de ácido úrico na pele do retalho foram menores que aqueles da pele normal, denotando estresse oxidativo local.

DESCRITORES - Retalhos cirúrgicos. Peroxidação lipídica. Ácido úrico. Ratos.

Correspondence:

Conflict of interest: none Financial source: none

Heitor Carvalho Gomes

Rua Napoleão de Barros, 715/4 andar

04024-900 São Paulo - SP

Tel: (11)5576-4118 - Fax: (11)5571-6579

Data do recebimento: $22 / 08 / 2003$

sandra.dcir@epm.br-heitorgomesmd@aol.com

Data da revisão: 16/09/2003

Data da aprovação: 09/10/2003 